DOI: $10.1515 /$ pts-2016-0027

\title{
MAGNETIC FIELD CONTROL OF COMBUSTION DYNAMICS
}

\author{
I. Barmina, R. Valdmanis, M. Zake, \\ Institute of Physics, University of Latvia, \\ 32 Miera Str., Salaspils, LV-2169, LATVIA, \\ e-mail:mzfisal.lv \\ H. Kalis, M. Marinaki, U. Strautins \\ Institute of Mathematics and Informatics, University of Latvia, Riga \\ 29 Raina Blvd., Riga, LV-1459, LATVIA \\ e-mail: kalis@lanet.lv
}

\begin{abstract}
Experimental studies and mathematical modelling of the effects of magnetic field on combustion dynamics at thermo-chemical conversion of biomass are carried out with the aim of providing control of the processes developing in the reaction zone of swirling flame. The joint research of the magnetic field effect on the combustion dynamics includes the estimation of this effect on the formation of the swirling flame dynamics, flame temperature and composition, providing analysis of the magnetic field effects on the flame characteristics. The results of experiments have shown that the magnetic field exerts the influence on the flow velocity components by enhancing a swirl motion in the flame reaction zone with swirl-enhanced mixing of the axial flow of volatiles with cold air swirl, by cooling the flame reaction zone and by limiting the thermo-chemical conversion of volatiles. Mathematical modelling of magnetic field effect on the formation of the flame dynamics confirms that the electromagnetic force, which is induced by the electric current surrounding the flame, leads to field-enhanced increase of flow vorticity by enhancing mixing of the reactants. The magnetic field effect on the flame temperature and rate of reactions leads to conclusion that field-enhanced increase of the flow vorticity results in flame cooling by limiting the chemical conversion of the reactants.
\end{abstract}

Keywords: combustion of volatiles, flame composition, magnetic field forces, mixing of reactants, swirling flow dynamics

\section{INTRODUCTION}

Different processes of thermo-chemical conversion of biomass, such as pyrolysis, gasification and combustion, have been developed to enhance the utilization of biomass residues (wood, straw, etc.) with large-scale variations of their composition and energy content determining variations of the heat and energy production and composition of the products. To provide stabilization of these processes, different types of combustion control can be used, such as swirl-enhanced stabilization of the 
flame reaction zone [1], co-firing of a biomass with fossil fuel [2], electro-dynamic [3], [4] and magnetic field [5], [6] control of combustion dynamics. The previous experimental study of the magnetic field effects on the flame formation and combustion characteristics has shown that application of the magnetic field to the flame can result in significant changes in flame shape, size and combustion characteristics due to development of the processes, which can be related to gradient magnetic fieldinduced mass transport of paramagnetic flame species [6]. In addition to gradient magnetic field effect on the mass transport of paramagnetic flame species development of combustion dynamics downstream, the combustor can be affected by the magnetic field-induced force, which acts on the movement of charged flame species. Thus, the main aim of the recent study is to provide a complex mathematical modelling and experimental study of the magnetic field-induced variations of the combustion dynamics with estimation of the effect, which can be related to the effect of the magnetic force on the movement of charged flame species (positive ions).

Mathematical model is developed with account of the axial and azimuthal components of flow velocity and development of the exothermic reaction of fuel combustion downstream the cylindrical combustor with radius $r_{0}$. The flame flow formation with axial velocity at the inlet of the combustor $\left(U_{0}\right)$ is affected by the radial $\left(B_{r}\right)$ and axial $\left(B_{z}\right)$ components of the axially symmetric magnetic field $B_{0}$. The magnetic field is induced by direct electric current of a density $j_{0}$ in a coil, which is placed at the inlet of the combustor, close to the inner surface of the combustor by surrounding the flame flow. The distribution of a stream function, azimuthal component of velocity $\left(V_{0}\right)$, vorticity and the formation of the velocity and temperature profiles are calculated by varying the electrodynamic force parameter $P_{e}=\frac{B_{0} j_{0} r_{0}}{\rho_{0} U_{0}^{2}}$ and swirl number $S=\frac{V_{0}}{U_{o}}$. The results of numerical simulation have shown that an increase of the electrodynamic force parameter $P_{e}$ results in a magnetic field-enhanced increase of the maximal flow velocity raising flow vorticity, whilst decreasing peak flame temperature and the rate of reaction.

\section{MATHEMATICAL MODELLING}

The present investigation continues the study of Choi, Rusak et al. [7] and Kalis et al. [8] by conducting a numerical investigation of the axially symmetric, steady swirling flow in a cylindrical pipe using the low Mach number approximation. The swirling flow with axial $\left(u_{z}\right)$, radial $\left(u_{r}\right)$, and azimuthal $\left(u_{\varphi}\right)$ components of velocity is developing downstream the pipe. The axial velocity determines the formation of a uniform stream in a central part of the cylindrical pipe-inlet. The azimuthal velocity with rotation of the part from tube inlet is obtained. Similar experiment with turbulent is considered in [9].

The approximate mathematical model takes into account the development of time-dependent exothermic reaction downstream the cylindrical pipe of radius $r^{\prime}=$ $\mathrm{r}_{0}=0.05[\mathrm{~m}]$ and of a length $\mathrm{z}=\mathrm{z}_{0}=0.1[\mathrm{~m}]$. The temperature dependence of the reaction rate is estimated using first-order Arrhenius kinetics. At the pipe inlet: $T_{0}=$ $300 \mathrm{~K}$, mass fraction of combustible reactant $C_{0}=1 \mathrm{~mol} / \mathrm{m}^{3}$ and flow density $\rho_{0}=1$ $\mathrm{kg} / \mathrm{m}^{3}$. 
The aim of mathematical modelling is to understand how a flow structure is affected by a direct electric current of density $j_{0}\left[\mathrm{~A} / \mathrm{m}^{2}\right]$ in the annular wire coil, which is positioned at the pipe inlet $(\mathrm{z}=0)$ close to the internal wall of the pipe (combustor) and surrounds the flame flow. At the pipe inlet, the uniform flow field formation with the axial flow velocity $\mathrm{U}=\mathrm{U}_{0}=0.01[\mathrm{~m} / \mathrm{s}]$ in the central part of a pipe $r^{\prime} \leq r_{1}^{\prime}=r_{0} / 2$ is considered.

The following dimensionless values

$$
\begin{aligned}
& r=\left(r_{0}\right)^{-1} r^{\prime} \in[0,1], x=\left(r_{0}\right)^{-1} z \in\left[0, x_{0}\right],\left(x_{0}=\left(r_{0}\right)^{-1} z_{0}=2\right), \\
& t=\left(r_{0} / U_{0}\right)^{-1} t^{\prime}>0, w=\left(U_{0}\right)^{-1} u_{z}, v=\left(V_{0}\right)^{-1} u_{\theta}, u=\left(U_{0}\right)^{-1} u_{r}, \\
& T=\left(T_{0}\right)^{-1} T^{\prime}, \rho=\left(\rho_{0}\right)^{-1} \rho^{\prime} \text { are used for numerical simulation. } V_{0} \text { is the } \\
& \text { maximal value of the azimuthal velocity. }
\end{aligned}
$$

The flow boundary $(\mathrm{r}=1)$ is subjected to a heat loss due to Newtonian cooling at temperature $T_{0}$ of surroundings and heat transfer coefficient $\mathrm{h}=0.1\left[\mathrm{~J} / \mathrm{sm}^{2} \mathrm{~K}\right]$.

The current in a coil induces the radial $B_{r}$ and axial $B_{z}$ components of the induced magnetic field $B$ in the ionized gas flow, which leads to the formation of the axial $F_{z}=-B_{r} j_{0}$ and radial $F_{r}=B_{z} j_{0}$ components of the electromagnetic force (Lorentz' force) $F$ and the azimuthal component of the curl of the force $f_{\phi}=\operatorname{rot}_{\phi} F=\partial F_{r} / \partial z-\partial F_{z} / \partial r^{\prime}$. From $\operatorname{div}(B)=\partial B_{r} / \partial r^{\prime}+\partial B_{z} / \partial z+B_{r} / r^{\prime}=0$ it follows that $f_{\phi}=-j_{0} B_{r} / r^{\prime}$.

The distribution of electromagnetic fields for the axially-symmetric system of electric current has been investigated and calculated similarly using the azimuthal component $\mathrm{A}_{\varphi}$ of the vector potential and the Biot-Savart law [10].

With this approximation:

$$
\begin{aligned}
& B_{r}=\frac{\mu I}{2 \pi} \frac{z}{c r^{\prime}}\left(\frac{z^{2}+r_{0}^{2}+r^{\prime 2}}{z^{2}+\left(r_{0}-r^{\prime}\right)^{2}} E(k)-K(k)\right), \\
& B_{z}=\frac{\mu I}{2 \pi c}\left(-\frac{z^{2}+r_{0}^{2}+r^{\prime 2}}{z^{2}+\left(r_{0}-r^{\prime}\right)^{2}} E(k)+K(k)\right), \\
& A_{\varphi}=\frac{\mu I}{2 \pi} \frac{1}{c}\left(\frac{2-k^{2}}{2} K(k)-E(k)\right), \text { where } k=2 \sqrt{r_{0} r^{\prime}} / c, \\
& c=\sqrt{\left(r_{0}+r^{\prime}\right)^{2}+z^{2}}, K(k), \quad E(k) \text { are the total elliptical inte- }
\end{aligned}
$$
gral of first and second kind, $\mathrm{B}_{\mathrm{s}}=-r^{\prime} \mathrm{A}_{\varphi}$ is the magnetic stream function, $B_{r}=\partial A_{\varphi} / \partial z, B_{z}=\partial A_{\varphi} / \partial r+A_{\varphi} / r^{\prime}$.

For numerical solutions we eliminate the modified pressure $\mathrm{p}^{*}$ from the hydrodynamic equations by introducing the stream function $\psi$ with the following expressions: 


$$
r \rho w=\partial \psi / \partial r, r \rho u=\theta \psi / \partial x(\rho=1 / T), \mathrm{p}^{*}=\mathrm{p}-\mathrm{j}_{0} \mathrm{~A}_{\varphi}, f_{\phi}=-j_{0} B_{r} / r^{\prime} .
$$

For deleting the source terms $u v / r, u \zeta / r$ in the equations, the transformation is used for the circulation $\widetilde{v}=v r$ and for modified vorticity $\widetilde{\zeta}=\zeta / r$. Then equations for vorticity and stream function are given by:

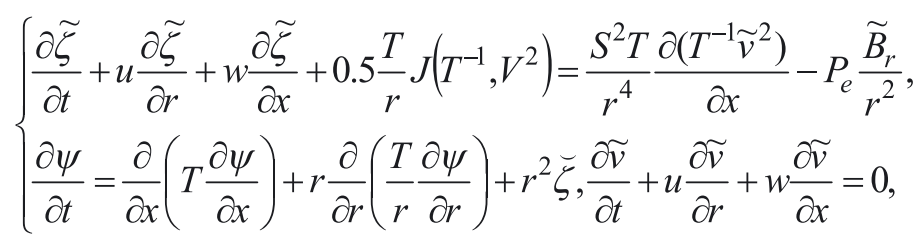

where the second equation for numerical simulation is transformed to non-steady, $V=\sqrt{u^{2}+w^{2}}$ is the module of velocity, $\widetilde{B}_{r}=\frac{B_{r}}{B_{0}}, \quad B_{0}=\frac{\mu I}{2 \pi r_{0}}=0.410^{-5} I[T]$, $J(a, b)=\frac{\partial a}{\partial x} \frac{\partial b}{\partial r}-\frac{\partial a}{\partial r} \frac{\partial b}{\partial x}$ is the Jacobian, $\zeta=\frac{\partial u}{\partial x}-\frac{\partial w}{\partial r}, P_{e}=\frac{B_{0} j_{0} r_{0}}{\rho_{0} U_{0}^{2}}$ is the elec$\partial x \partial r \quad \partial r \partial x$
trodynamical force parameter, $S=\frac{V_{0}}{U_{0}}$ is the swirl number.

2-D reaction-diffusion equation system of two nonlinear partial differential equations is used to estimate the formation of the flow temperature and composition fields:

$$
\left\{\begin{array}{l}
\frac{\partial T}{\partial t}+u \frac{\partial T}{\partial r}+w \frac{\partial T}{\partial x}=\frac{L_{e}}{\rho P e} \Delta T+\beta A C \exp \left(-\frac{\delta}{T}\right) \\
\frac{\partial C}{\partial t}+u \frac{\partial C}{\partial r}+w \frac{\partial C}{\partial x}=\frac{1}{\rho P e} \Delta C-A C \exp \left(-\frac{\delta}{T}\right)
\end{array}\right.
$$

where $\rho T=1 . P e=\frac{\rho_{0} U_{0} r_{0}}{D}=10, L_{e}=\frac{\lambda}{c_{p} D}=1$ are Peclet and Lewis numbers, $\beta=\frac{B}{c_{p} T_{0}}=5$ is the heat-release parameter, $\delta=\frac{E}{R T_{0}}=10-$ the scaled activationenergy, $\Delta$ is the Laplace operator, $D=5 . e-5\left[\mathrm{~m}^{2} / \mathrm{s}\right]$ is the molecular diffusivity, $\lambda=5 . e-2[\mathrm{~J} / \mathrm{smK}]-$ the thermal conductivity, $\quad c_{p}=1000[\mathrm{~J} / \mathrm{kg} \mathrm{K}]-$ the specific heat at constant pressure, $B=1.5 e+6[\mathrm{~J} / \mathrm{kg}], \quad A=\frac{A^{\prime} r_{0}}{U_{0}}\left(A^{\prime}=1 . e+4[1 / \mathrm{s}]\right), \quad E=2.5 e+4[\mathrm{~J} / \mathrm{mol}] \quad$ are the specific heat release, the pre-exponential factor of reaction rate and the activation energy, $R=8.314[\mathrm{~J} / \mathrm{mol} \mathrm{K}]-$ the universal gas constant. 
The boundary conditions are the following:

1) along the axis $r=0-\widetilde{v}=0, \psi=0, \partial T / \partial r=\partial C / \partial r=\partial \widetilde{\zeta} / \partial r=0$ (the symmetry conditions),

2) at the wall $\mathrm{r}=1-\tilde{v}=0, \quad \psi=q, \quad \tilde{\zeta}=0, \quad \partial T / \partial r=\partial C / \partial r=0$,

3) at the pipe outlet $\mathrm{x}=\mathrm{x}_{0}$ -

$u=0, \partial T / \partial x=\partial C / \partial x=\partial \widetilde{\zeta} / \partial x=\partial \widetilde{v} / \partial x=\partial \psi / \partial x=0$,

4) at the pipe inlet $\mathrm{x}=0-u=0, \tilde{\zeta}=0 T=1$, for $r \in[0,1]$ and $w=1, C=1$, $\psi=0.5 r^{2}, \widetilde{v}=0$, for $r \in\left[0, r_{1}\right] ; \psi=q, \widetilde{v}=4 r \frac{\left(r-r_{1}\right)(1-r)}{\left(1-r_{1}\right)^{2}}, w=0, C=0-$

we have uniform jet flow by $r<r_{1}$ and rotation by $r>r_{1}$ with maximal azimuthal velocity 1 by $r=\left(1-r_{1}\right) / 2$.

Here $B i=\frac{h r_{0}}{\lambda}$ is the Biot number, $q=\frac{r_{1}^{2}}{2}$ is the dimensionless fluid volume. The dimensionless radial and axial distribution of the magnetic field induction and magnetic field stream $\left(\mathrm{B}_{\mathrm{r},} \mathrm{B}_{\mathrm{z}}\right.$ and $\left.\mathrm{B}_{\mathrm{s}}\right)$ for $B_{0}=1$ is represented in Fig. 1, a-c.

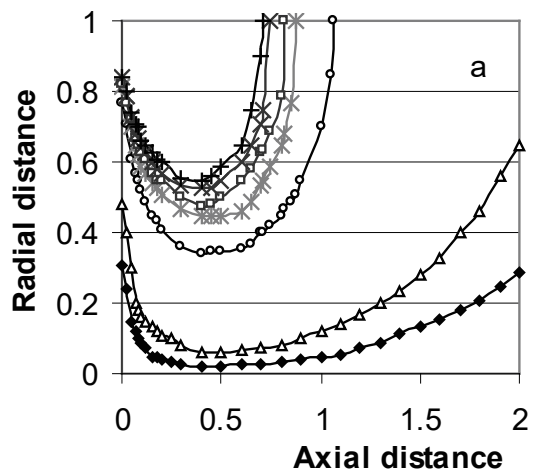

$\begin{array}{lll}\longrightarrow \mathrm{Br} ; 0.05 & \rightarrow-0.1 & \square-0.5 \\ \rightarrow-0.7 & \longrightarrow 0.8 & \times 0.9\end{array}$
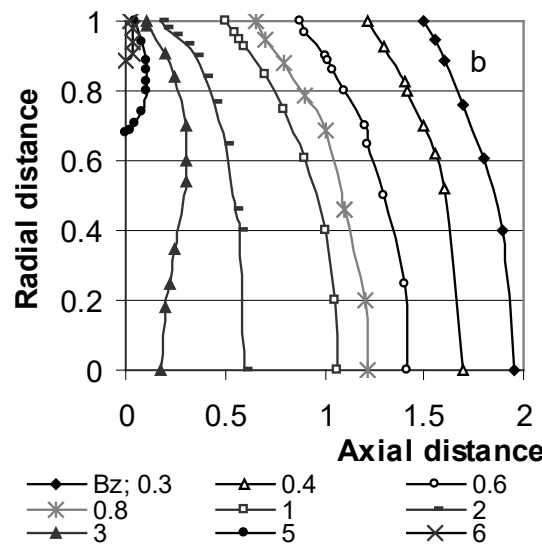

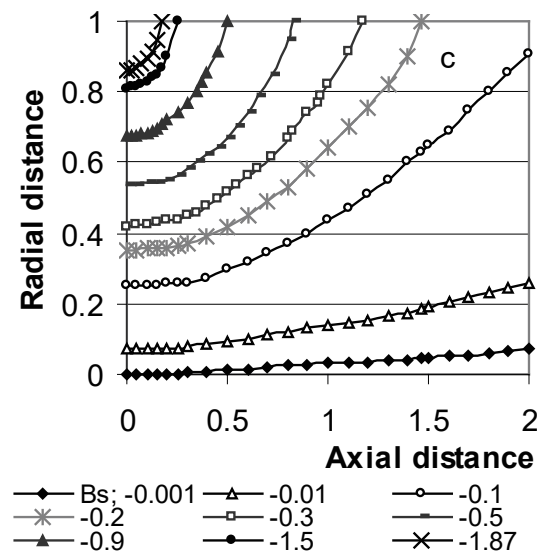

Fig. 1. The dimensionless distribution of the axial and radial components $(\mathrm{a}, \mathrm{b})$ of the magnetic field induction and magnetic field stream function (c). 
The approach seeks the steady solution as the time asymptotic limit of the solutions of the unsteady equations. The distribution of stream function, azimuthal component of velocity, vorticity (Fig. 2) and temperature (Fig. 3) has been calculated using the implicit FDS with the upwind differences in the space, ADI method and under-relaxation.

For numerical simulation, the following parameters are used: $\mathrm{S}=1 ; 3, \mathrm{r}_{1}=0.5$, $\mathrm{A}=50000, B i-0.1, \mathrm{P}_{\mathrm{e}}=0 ; 0.1 ; 0.5 ; 1, \tau=0.0008, I t=2500$ (number of iterations or time steps).

The results of numerical simulation are given in Table 1 , where $T_{a v}$ is the averaged value of the flow temperature and $\widetilde{R}=A C \exp (-\delta / T)$ is the reaction rate.

Table 1

The values of $P_{e}, S, T_{a v}, \max U, \max \widetilde{R}, \max T, \max |\zeta|, \min \psi$ for $x_{0}=2$

\begin{tabular}{|c|c|c|c|c|c|c|c|}
\hline$P_{e}$ & $S$ & $T_{a v}$ & $\max U$ & $\max R$ & $\max T$ & $\max |\zeta|$ & $\min \psi$ \\
\hline 0.0 & 1 & 3.000 & 5.402 & 805.97 & 5.877 & 137.61 & 0 \\
\hline 0.5 & 1 & 2.883 & 5.463 & 805.29 & 5.873 & 139.85 & -0.0056 \\
\hline 1.0 & 1 & 2.759 & 5.545 & 804.97 & 5.861 & 143.38 & -0.0460 \\
\hline 0.0 & 3 & 2.994 & 5.409 & 805.94 & 5.877 & 137.96 & 0 \\
\hline 0.1 & 3 & 2.975 & 5.422 & 805.86 & 5.876 & 138.05 & 0 \\
\hline 0.5 & 3 & 2.880 & 5.477 & 805.24 & 5.873 & 140.00 & -0.0061 \\
\hline 1.0 & 3 & 2.733 & 5.579 & 805.07 & 5.862 & 145.20 & -0.0524 \\
\hline
\end{tabular}
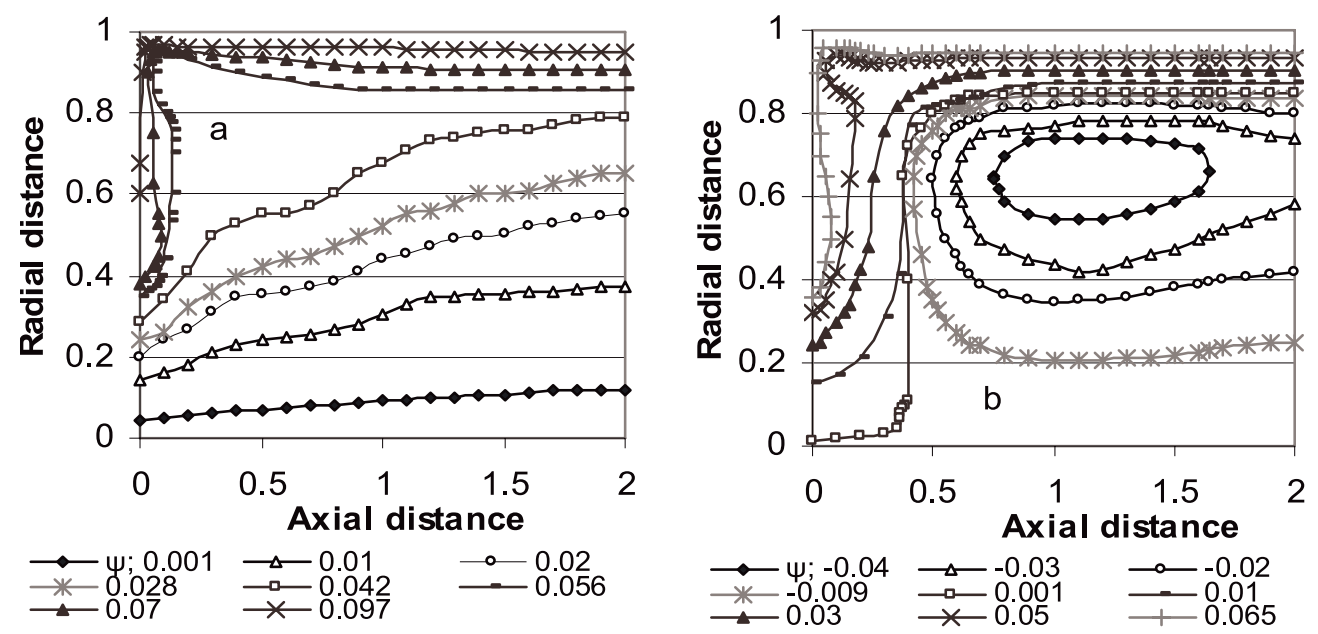

Fig. 2. Magnetic field effect on the swirling flow stream function:

$$
\text { a) } \left.\mathrm{P}_{\mathrm{e}}=0 ; \mathrm{S}=1 ; \mathrm{b}\right) \mathrm{P}_{\mathrm{e}}=1 ; \mathrm{S}=1 \text {. }
$$



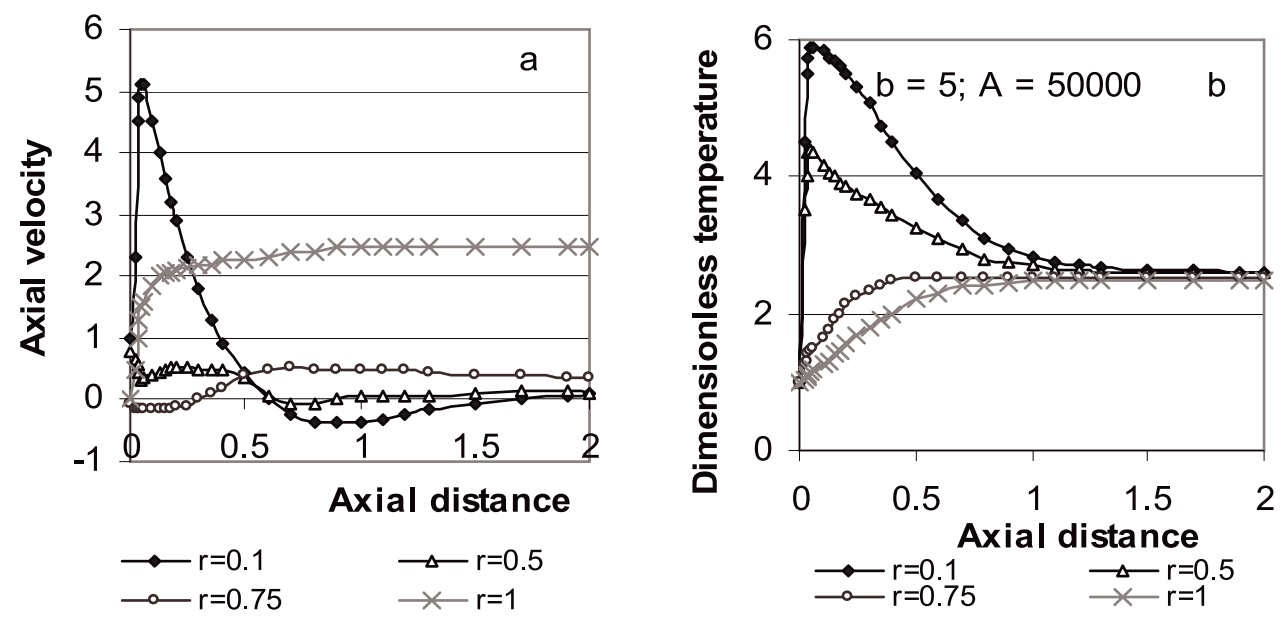

Fig. 3. The formation of dimensionless profiles of the axial velocity (a) and temperature (b) for swirling flame flow; $\mathrm{Pe}=0.5 ; \mathrm{S}=3$.

\section{EXPERIMENTAL PART}

Experimental study of the magnetic field effect on the combustion characteristics at thermo-chemical conversion of wood pellets was carried out using a batchsize device with integrated biomass gasifier and water cooled combustor (Fig. 4). Axially-symmetric magnetic field is applied to the flame using two coils, which are fed with a direct current. Magnetic field with induction up to $50 \mathrm{mT}$ acts on the flame volume from the bottom of the combustor up to a distance $L / D \approx 2$ from the centre of coils. The propane flame flow (2) is used to supply additional heat energy into the upper part of biomass pellets at an average rate of $1 \mathrm{~kJ} / \mathrm{s}$ to initiate the biomass gasification and the formation of the axial flow of volatiles at the inlet of the combustor. The primary air is supplied below the layer of biomass pellets at an average rate of 30-40 1/min to support a thermal decomposition of main biomass components (3). Secondary swirling air is supplied (4) above the layer of biomass at an average rate of $65 \mathrm{l} / \mathrm{min}$ and is used to provide the swirl-enhanced combustion of the volatiles developing downstream the water-cooled combustor (6).

To estimate the magnetic field effect on the combustion dynamics at thermochemical conversion of biomass, the local measurements of the flame velocity, temperature and composition are carried using a Pitot tube and a gas analyzer Testo-350 XL. The local measurements of the flame composition, temperature and velocity were carried out at distance $\mathrm{z} / \mathrm{D}=2.8$ above the secondary air inlet nozzle close to the coils of electromagnet $(\mathrm{z} / \mathrm{D} \approx 0.2)$. In addition, the local online measurements of the flame temperature using $\mathrm{Pt} / \mathrm{Pt} / \mathrm{Rh}$ thermocouples were carried out at the end stage of the combustion of volatiles - at distance $\mathrm{x} / \mathrm{D}=6.6$ above the secondary air inlet nozzle. Produced heat energy was estimated from calorimetric measurements of cooling water flow of the combustor using the PC-20 control unit. 

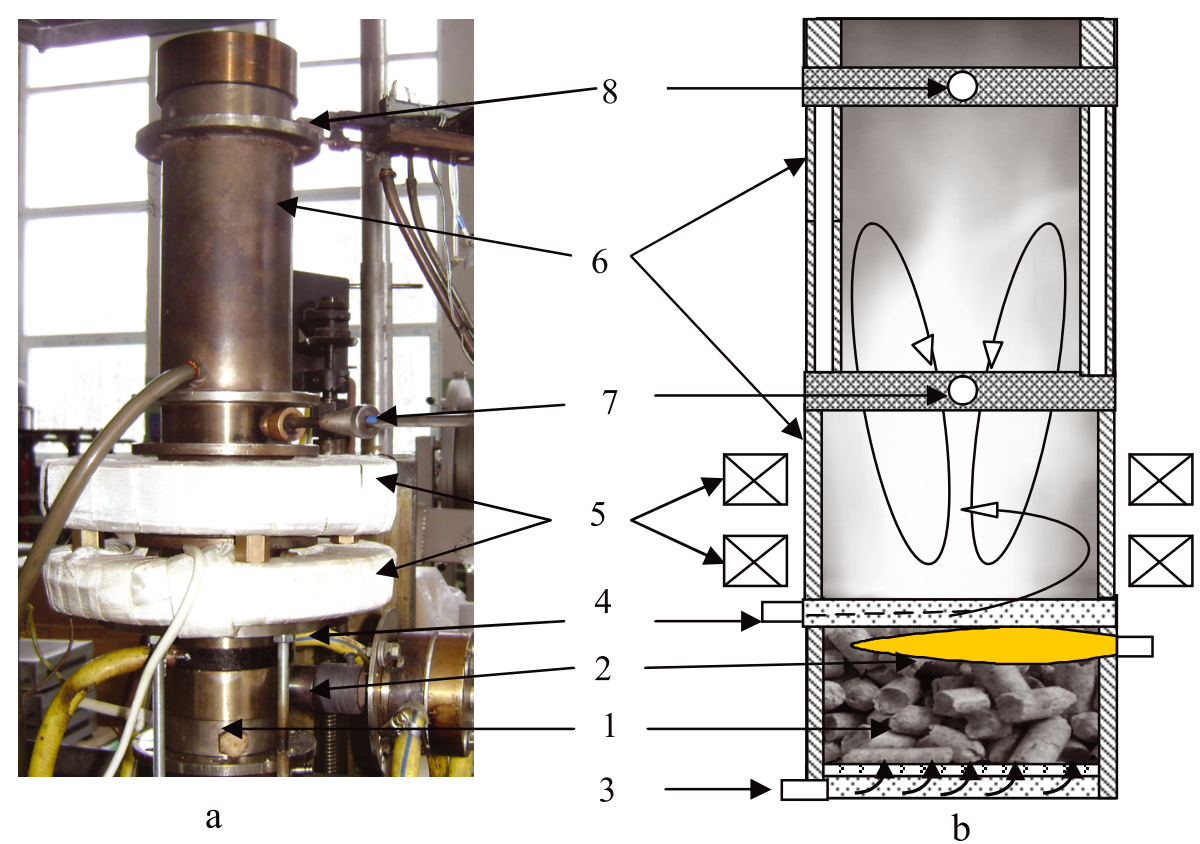

Fig. 4. A photo (a) and sketch (b) of the experimental device: biomass gasifier (1), propane flame nozzle (2), primary air supply nozzle (3), secondary air swirl nozzle (4), coils of electromagnet (5), water-cooled combustor (6), diagnostic sections $(7,8)$.

\section{RESULTS AND DISCUSSION}

\subsection{Experimental Results}

The formation of the flow velocity field downstream the combustor for given configuration of a pilot device is influenced by the two main factors - the axial flow of volatiles $\left(\mathrm{CO}, \mathrm{H}_{2}, \mathrm{CH}_{4}\right)$, which is determined by the thermal decomposition of biomass pellets and is supported by primary air supply, and combustion of volatiles, which is supported by secondary azimuthal air supply at the bottom of the conductor. The resulting flow field of the undisturbed flame flow $(\mathrm{B}=0)$ above the coils $(\mathrm{L}=$ $20 \mathrm{~mm}$ ) indicates the formation of the relatively uniform axial velocity profile across the flow centerline $(\mathrm{r} / \mathrm{R}<0.7)$ with average value of the axial flow velocity $1.3 \mathrm{~m} / \mathrm{s}$ and large gradients of the axial and azimuthal flow velocity components and swirl intensity in the near vicinity of the channel walls $(r / R>0.7)$.

The application of the magnetic field to the flame disturbs the flow velocity profiles determining the field-induced variations of the local and average values of the axial $\left(\mathrm{u}_{\mathrm{z}}\right)$, azimuthal $\left(\mathrm{u}_{\varphi}\right)$ flow velocity and swirl intensity) above the coils (Fig. $5, a, b)$. 

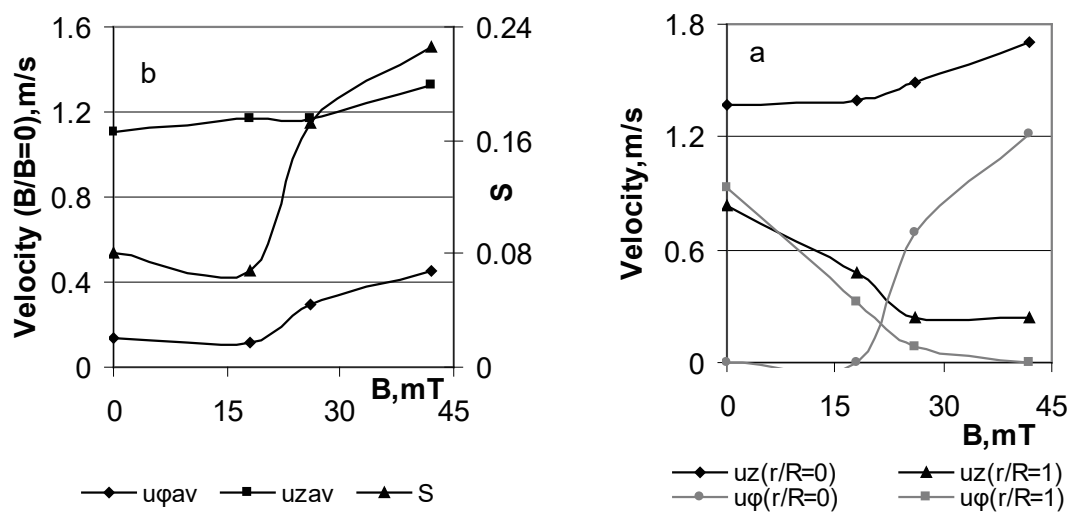

Fig. 5. The magnetic field effect on the local (a) and average values of the axial and tangential flow velocity and flow swirl number (b).

Along the outside part of the flame reaction zone $(\mathrm{r} / \mathrm{R}>0.7)$ the magnetic field-induced force slows down the axial and tangential flow velocity (Fig. 5-a) by enhancing the axial and swirl motion in the flame centerline $(\mathrm{r} / \mathrm{R}<0.7)$ with correlating increase of the average values of the axial, azimuthal flow velocities and swirl intensity (Fig. 5 b). The results of mathematical modelling have shown a similar increase of the flow vorticity by increasing the magnetic field-induced Lorentz force and magnetic force parameter $P_{e}$ (Table 1). This allows suggesting that the magnetic field-induced variation of the average values of the flow velocity components and swirl intensity can be related to the effect of Lorentz force. As follows from Fig. 5, more pronounced magnetic field-induced variations indicate the azimuthal flow velocity component $u_{\varphi}$, for which the instant velocity vector of charged flame species $\boldsymbol{u}_{\varphi}$ is oriented perpendicularly to the magnetic field $\boldsymbol{B}$ determining the formation of the magnetic force $\boldsymbol{F}_{\boldsymbol{m}}=q_{i} \boldsymbol{u}_{\varphi} \times \boldsymbol{B}$.

Moreover, from the results of numerical modelling (Table 1) it follows that the field-induced variations of the average values of the flow velocity and vorticity correlate with a field-enhanced decrease of the average and peak flame temperatures. Similar decrease of the local and average values of the flame temperature above the coils follows from the results of the experimental study indicating the field-enhanced correlating decrease of the volume fraction of $\mathrm{CO}_{2}$, combustion efficiency and produced heat energy by increasing the magnetic field induction (Fig. 6, a-d).
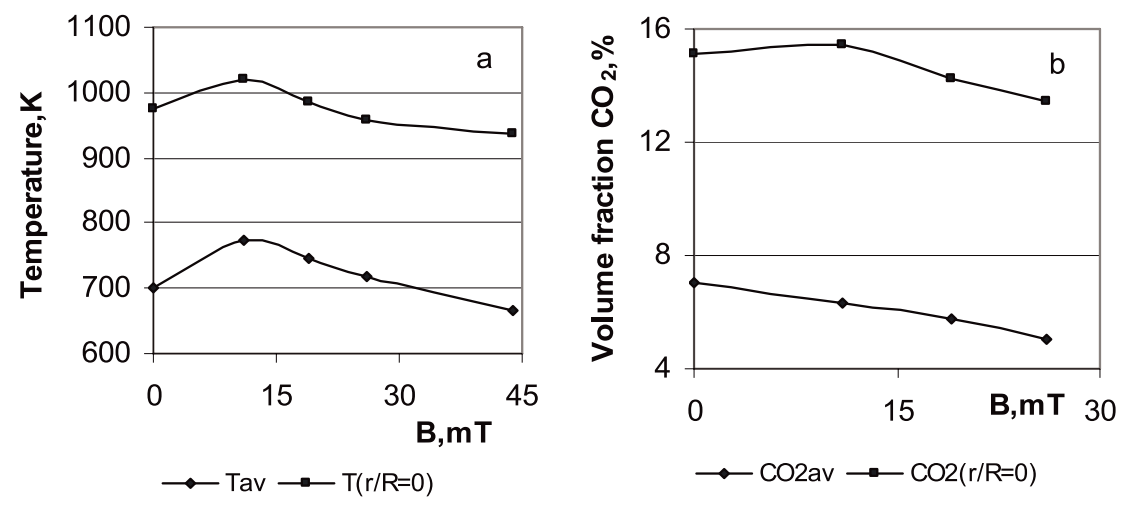

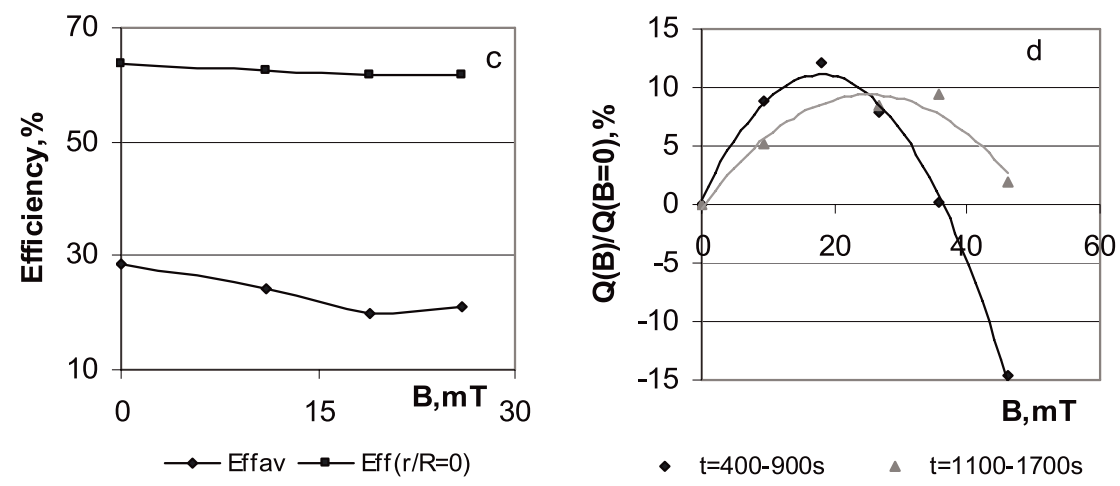

Fig. 6. The magnetic field effect on the main combustion characteristics above the coils.

Moreover, in accordance with the results of mathematical modelling, the measurements of the flame composition profiles confirm the field-induced decrease of the reaction rates by increasing the external magnetic force, which results in an increase of the mass fraction of unburned volatiles $\left(\mathrm{CO}, \mathrm{H}_{2}\right)$ at the interface between the axial fuel flow and air swirl with field-enhanced increase of the local and average values of the air excess and correlating decrease of combustion efficiency along the outer part of the flame reaction zone. This correlation confirms the field-enhanced mixing of the axial flow of volatiles with cold air flow with resulting cooling of the flame reaction zone, which shows the direct influence on combustion dynamics by increasing the mass fraction of unburned volatiles and air excess at the interface between the axial flow of volatiles and air swirl decreasing combustion efficiency above the coils. It should be noticed that magnetic field improved mixing of the flame components along the interface is confirmed by the results of the experimental study of magnetic field effect on diffusion flames, which confirm the field-induced forcing of the oxidant stream into fuel stream [11]. By considering the impact of magnetic field effect on the mixing of the reactants, which results in cooling of the flame reaction zone, it is concluded that to restrict the field-induced decrease of the flame temperature, there is a need to provide the additional heat energy supply into the secondary swirling air flow as it follows from the results of experimental study of the magnetic field effects on the flame formation by co-firing the biomass pellets with gas (propane) [6].

\section{CONCLUSIONS}

The present research incorporates the mathematical modelling and experimental study of swirling flame behavior in the presence of magnetic field. Based upon the results of mathematical modelling and experimental study, the following conclusions have been drawn.

The results of mathematical modelling have shown that the magnetic field exerts the influence on the flow dynamics and the formation of the flow stream function indicating an increase of the flow vorticity and the local and average values of the flow velocity. An increase of the flow vorticity results in an enhanced mixing of 
the reactants by cooling the flame reaction zone and decreasing the rate of reactions.

The results of mathematical modelling are confirmed by the experimental study of the magnetic field effects on the swirling flow dynamics and the formation of the reaction zone with estimation of the effects, which can be related to the effect of magnetic force on the azimuthal movement of charged flame species, indicating the magnetic field-enhanced swirl motion along the centerline of the flame reaction zone $(\mathrm{r} / \mathrm{R}<0.7)$ with dominant field effect on swirl-enhanced mixing of the axial flow of volatiles with cold air swirl.

The field-enhanced mixing of the axial flow of volatiles with cold air flow results in cooling of the flame reaction zone. The flame cooling slows down the rate of reactions with local variation of the combustion characteristics - an increase of the mass fraction of unburned volatiles, decrease of the combustion efficiency and produced heat energy.

\section{ACKNOWLEDGEMENTS}

The authors deeply acknowledge the financial support of the Latvian research grant No.623/14 and of the University of Latvia grant No. 6012-A55.2/48.

\section{REFERENCES}

1. Gupta, A.K., Lilley, D.G., \& Syred, N. (1984). Swirl flows. Abacus Press UK, 588.

2. Sami, M., Annamalai, K., Woldridge, M. (2001). Cofiring of coal and biomass fuel blends. Prog. Energy Combustion Sci. 27, 171-214.

3. Lawton, J., Weinberg, F.J. (1969). Electric aspects of combustion. Clarenton Press, 336340 .

4. Colannino, J. (2012). Electrodynamic combustion control, TM technology. A Clear Sign White Paper, ClearSign Combustion Corporation, Seattle. Available at www.clearsigncombustion.com

5. Swaminathan, S. (2005). Effects of magnetic field on micro flames. A Thesis of Master of Science in Mechanical Engineering at the Department of Mechanical Engineering, 125. Available at http://etd.lsu.edu/docs/available/etd-11182005-092209/unrestricted/ Swaminathan_thesis.pdf

6. Barmina, I., Lickrastina, A., Suzdalenko, V., \& Zake, M. (2012). Gradient magnetic field promotion of pelletized biomass combustion. Magnetohydrodynamics 48, 351-360.

7. Choi, J.J., Rusak, Z., \& Kapila, A.K. (2007). Numerical simulation of premixed chemical reactions with swirl. Combustion Theory and Modelling 6 (11), 863-887.

8. Kalis, H., Marinaki, M., Strautins, U., \& Lietuvietis O. (2015). On the numerical simulation of the combustion process with simple chemical reaction. Proc. of the 7th Baltic Heat Transfer conf. "Advances in Heat Transfer”, 24-26 Aug. 2015, (pp. 175-180).

9. Buikis, A., \& Kalis, H. (2004). Flow and temperature calculation of electrolyte for a finite cylinder in the alternating field of finite number circular wires. Magnetohydrodynamics 40 (1), 77-90.

10. Buikis, A., \& Kalis, H. (2004). Creation of temperature field in a finite cylinder by alternated electromagnetic force. Progress in Industrial Mathematics at ECMI 2002, 247 251. 
11. Thompson, J.I. (1994). Computational modeling of Lorentz force induced mixing in alkali seeded diffusion flames. A thesis for the degree of Master of Science. Oregon State University. Available at

12. https://ir.library.oregonstate.edu/xmlui/bitstream/handle/1957/35563/ThompsonJonIra1995.pdf?sequence $=1$

\section{MAGNĒTISKĀ LAUKA IETEKME UZ DEGŠANAS PROCESU DINAMIKU}

I. Barmina, R. Valdmanis, M. Zaķe, H. Kalis M. Marinaki, U. Strautiňš

Kopsavilkums

Ir veikti kompleksi pētījumi par magnētiskā lauka ietekmi uz liesmas virpuḷplūsmu dinamiku, kas apvieno plūsmas matemātisko modelēšanu un eksperimentālos pētījumus, izvērtējot galvenos faktorus, kas ietekmē šo plūsmu dinamikas veidošanos magnētisko spēku laukā.

Plūsmas dinamikas matemātiskā modelēšana apliecina, ka magnētiskais lauks izraisa plūsmas struktūras izmaiņas, intensificējot lokālu virpuḷu veidošanos reakcijas zonā, kas izraisa plūsmas vidējā ātruma palielināšanos ar vienlaicīgu reakcijas zonas vidējās un maksimālas temperatūras samazināšanos, kas līdz ar to samazinot ķīmisko reakciju ātrumu degšanas zonā.

Līdzīgs rezultāts ir iegūts, arī veicot eksperimentālos pētījumus par magnētiskā lauka ietekmi uz virpuļplūsmas dinamiku, sastāvu un temperatūru, kas apliecina, ka plūsmas azimutālā ātruma izmaiņas magnētiskā laukā sekmē gaistošo savienojumu aksiālās plūsmas sajaukšanos ar gaisa virpuḷplūsmu, izraisot degšanas zonas temperatūras, degšanas procesu efektivitātes un saražotā siltuma daudzuma samazināšanos, ierobežojot gaistošo savienojumu degšanas zonas veidošanos.

01.06.2016. 